\title{
Perbandingan Personality Traits, Rasa Bersalah dan Rasa Malu Pengedar Narkoba: Nonresidivis Versus Residivis
}

\section{Comparison of Personality Traits, Guilt and Shame of Drug Dealers: Non-Recidivists Versus Recidivists}

\author{
Imaduddin Hamzah, Iman Santoso \\ Politeknik Ilmu Pemasyarakatan, Depok, Indonesia
}

\begin{abstract}
Various researches on drug abuse crimes have focused more on drug users or addicts. Meanwhile, investigations into drug dealers and producers have received very little attention. The majority of drug convicts in prisons are drug traffickers, which has resulted in a significant increase in drug trafficking cases in Indonesia. This study aimed to identify differences in personality traits, guilt, and shame of non-recidivists and drug dealers. The research was conducted on one hundred and fifty-five prisoners at the Cibinong Penitentiary, West Java, Indonesia. The measurement uses a scale of the big five personality traits which has been adapted into Indonesian, and the Guilt and Shame Proneness Scale (GASP) was developed by Cohen, Wolf, Panter, and Insko. This study found that there were differences in personality traits in terms of agreeableness and neuroticism between non-recidivists and recidivists. The difference test concluded that guilt and shame did not show any differences between the two groups of prisoners. This conclusion can provide a basis for consideration of developing a program to develop drug trafficking convicts to prevent the re-offense of crimes after being released.
\end{abstract}

Keywords : Personality traits, guilt, shame, non-recidivists, recidivists

\begin{abstract}
Abstrak. Berbagai penelitian kejahatan penyalahgunaan narkoba selama ini lebih memfokuskan pada pengguna atau pecandu narkoba. Sedangkan penyelidikan terhadap para pengedar dan produsen narkoba masih sangat kurang mendapatkan perhatian. Mayoritas narapidana kejahatan narkoba di lembaga pemasyarakatan adalah para pengedar narkoba yang mengakibatkan peningkatan yang signifikan dalam kasus peredaran obat terlarang di Indonesia. Studi ini bertujuan untuk mengidentifikasi perbedaan dalam sifat kepribadian, rasa bersalah, dan rasa malu nonresidivis dan residivis pengedar narkoba. Penelitian dilakukan pada seratus lima puluh lima narapidana di Lembaga Pemasyarakatan Cibinong, Jawa Barat, Indonesia, Pengukuran menggunakan skala the big five personality traits yang telah diadaptasi ke dalam bahasa Indonesia dan Guilt and Shame Proneness Scale (GASP) dikembangkan oleh Cohen, Wolf, Panter dan Insko. Studi ini menemukan ada perbedaan personality traits dalam aspek pada agreeableness dan neuroticism nonresidivis dengan residivis. Uji perbedaan menyimpulkan rasa bersalah dan rasa malu tidak menunjukkan perbedaan antara kedua kelompok narapidana. Kesimpulan ini dapat memberikan dasar pertimbangan pembuatan program pembinaan narapidana pengedar narkoba untuk mencegah pengulangan kejahatan setelah bebas.
\end{abstract}

Kata kunci: Personality traits, rasa bersalah, rasa malu, nonresidivis, residivis

Korespondensi tentang artikel ini dapat dialamatkan kepada Imaduddin Hamzah melalui e-mail: imaduddn@poltekip.ac.id 
Jumlah kasus kejahatan narkoba di Indonesia menunjukkan peningkatan yang signifikan. Data Sistem Database Pemasyarakatan (2020) terkait narapidana dan tahanan kasus penyalahgunaan narkoba tahun 2015-2019 menunjukkan kenaikan rata-rata $22 \%$ per tahun. Pertumbuhan setiap tahun angka narapidana berstatus sebagai bandar atau pengedar narkoba lebih tinggi (24\%) daripada pengguna narkoba (17\%). Data ini juga menunjukkan pelaku kejahatan bandar atau pengedar narkoba berjumlah 88.944 orang dari total 138.927 narapidana kasus narkoba, dan merupakan angka terbesar narapidana dan tahanan baik di lembaga pemasyarakatan (Lapas) maupun di rumah tahanan (Rutan) di seluruh Indonesia selama periode tahun 2015-2019. Data tersebut mengindikasikan pertumbuhan jumlah pengedar narkoba yang semakin banyak dan luas, yang dapat berdampak pada konsumen atau pengguna baru yang semakin tinggi. Para pengedar atau bandar adalah aktor utama dari peningkatan jumlah peredaran narkoba yang semakin meningkat di masyarakat.

Meskipun fakta menunjukkan jumlah pengedar narkoba merupakan mayoritas di dalam Lapas, namun kebijakan pemerintah tentang rehabilitasi penyalahgunaan narkoba masih lebih memprioritaskan pada pecandu narkoba dengan membangun berbagai pusat rehabilitasi dan mengembangkan program terapinya. Pada tahun 2019, tercatat 108 pusat rehabilitas rawat inap untuk pecandu narkoba telah dibangun dan dikelola oleh pemerintah (BNN, 2019). Demikian halnya juga pembinaan dan rehabilitasi narapidana kasus narkoba di lembaga pemasyarakatan di Indonesia masih difokuskan pada narapidana penyalahguna dan ketergantungan narkoba, seperti terapi komunitas dan rehabilitasi medis (Delinda, 2017; Nainggolan, 2019). Bachtiar (2020) dalam studinya menemukan dari 64 narapidana narkotika residivis, hanya lima saja yang mengikuti program pembinaan kemandirian. Hal ini menunjukkan rehabilitasi terhadap narapidana sebagai pengedar narkoba masih minim.

Data statistik kriminal (BPS, 2020) memperlihatkan terjadi peningkatan jumlah kasus penyalahgunaan atau pengedaran narkoba di wilayah Indonesia yakni 4103 kasus pada 2011, 5931 kasus pada 2014 dan terus meningkat menjadi 12579 kasus pada 2018. Masih lemahnya program pembinaan narapidana setelah bebas, baik secara kualitas maupun kuantitas, mempengaruhi rendahnya upaya pencegahan narapidana agar tidak mengulangi tindak kejahatan kembali (Pamungkas, 2014).

Menurut Undang-undang (UU) No. 12 Tahun 1995, lembaga pemasyarakatan adalah tempat untuk melaksanakan pembinaan narapidana dan anak didik pemasyarakatan. Para narapidana kasus narkoba yang dinyatakan bersalah (sebagai pengedar dan pecandu) dengan putusan hakim dapat ditempatkan pada lapas umum maupun lapas khusus narkotika. Di dalam lapas, para pengedar narkoba dengan status residivis berinteraksi dengan para pengedar narkoba yang baru pertama kali mengalami hukuman penjara (nonresidivis).

Residivis adalah orang yang pernah dihukum karena tindak kejahatan dan mengulangi tindak kejahatan yang serupa atau kejahatan lain setelah bebas (Morgan \& Del Fabbro, 2018). Studi prisonisasi yang dilakukan menemukan suatu bentuk negatif interaksi yang dapat menyebabkan munculnya pembelajaran kejahatan dengan para residivis. Selama dalam penjara, narapidana mengalami proses pembelajaran melalui interaksi antar narapidana yang dilakukan secara intensif seperti saling bertukar informasi, pengalaman, bahkan kultur kriminal yang akhirnya dapat menciptakan narapidana residivis di kemudian hari (Hudzaifi, 2017). Bernes dan Teeters (dikutip oleh Angkasa, 2010) menyatakan bahwa penjara mempunyai dampak negatif bagi para pendatang baru di dunia kejahatan ketika para penjahat kebetulan (accidental offenders) dirusak melalui pengalaman-pengalamannya dalam berinteraksi dengan penjahat kronis. Penjelasan tersebut menegaskan 
bahwa penjara memiliki potensi sebagai tempat para narapidana mentransfer wawasan dan keahliannya dalam tindakan kejahatan satu dengan yang lainnya. Pengedar narkoba tidak berpengalaman dapat belajar dari pengedar narkoba berpengalaman dan criminal career (Duck, 2014).

Penelitian sebelumnya tentang penyalahgunaan narkoba pada umumnya lebih diarahkan pada subjek berstatus pecandu dibandingkan dengan para subjek sebagai pengedar narkoba. Penelitian psikologis terhadap subjek para pecandu narkoba menyelidiki, misalnya, faktor determinan kepribadian (Zilberman, Yadid, Efrati, Neumark, \& Rassovsky, 2018), penggunaan metode rehabilitasi terapi komunitas (Falkin, Wexler, \& Douglas S. Lipton, 1992) dan efek terapi kelompok (Lo Coco et al., 2019; Prendergast, Podus, Chang, \& Urada, 2002).

Sejumlah studi yang mencoba mengeksplorasi subjek pengedar narkoba pernah dilakukan, namun masih terbatas. Risetriset itu menjelaskan adanya daya tarik dari penjualan narkoba berhubungan dengan konsekuensi negatif akibat peningkatan persoalan faktor struktural, seperti kondisi kekurangan ekonomi, peluang pendidikan yang buruk, pengangguran yang tinggi, status ekonomi, jaringan keluarga dan pertemanan (Highland \& Dabney, 2009; Duck, 2014). Studi lain menemukan bahwa secara tradisional motivasi pengedar narkoba dikaitkan dengan keserakahan individu atau tekanan struktural sosial akibat dari kondisi sosial yang buruk (Highland \& Dabney, 2009), rasa permusuhan yang tinggi dan kecemasan (Semple, Strathdee, Volkmann, Zians, \& Patterson, 2011).

Studi psikologi yang mengkaji aspek kepribadian pada perilaku kejahatan juga teah dilkaukan. Misalnya Sinha (2016) telah mengidentifikasi adanya perbedaan faktor kepribadian antara kelompok sampel normal dan narapidana. Highland dan Dabney (2009) juga menemukan hubungan positif antara emosi negatif dan perdagangan narkoba. Pedagang narkoba me- nunjukkan karakteristik kepribadian yang berbeda dengan kelompok sampel normatif nonpenjahat. Pengedar narkoba mendekati profil penjahat umumnya, dengan kekhususan, mereka tampaknya termotivasi untuk menjual obat-obatan karena faktor keserakahan, status sosial, atau memenuhi kebutuhan dirinya sendiri untuk mengkonsumsi narkoba (Highland \& Dabney, 2009). Hasil penelitian oleh Međedović, Kujačić, dan Knežević (2012) menyatakan bahwa kepribadian yang paling menonjol dan signifikan pada pengedar narkoba adalah adanya sifat-sifat psikopat atau kepribadian antisosial. Mereka juga tidak memiliki gambaran diri sebagai pengedar narkoba, karena menilai diri masuk dalam aktivitas pengedar atas keputusan yang dibuat secara tidak sadar (Tunnell, 1993).

Temuan van Dam, Janssens, dan De Bruyn (2005) menyimpulkan bahwa secara statistik ada perbedaan yang signifikan antara nonresidivis dan residivis, dengan bukti skor para residivis secara signifikan lebih tinggi pada neuroticism dan lebih rendah pada agreeableness. Namun, temuan ini berbeda dengan hasil penelitian dari Clower dan Bothwell (2001) yang mengungkapkan bahwa conscientiousness dan openness secara negatif berkorelasi dengan kuantitas pernah ditangkap pada narapidana. Aspek neuroticism, extraversion, dan agreeableness juga tidak secara signifikan berhubungan dengan jumlah berapa kali ditangkap, namun kombinasi rendahnya conscientiousness dan openness secara substansial behubungan dengan peningkatan jumlah penangkapan.

Selain penelitian tentang aspek kepribadian, penelitian tentang moral emosi yaitu rasa bersalah (guilt) dan rasa malu (shame) pada pelaku kejahatan umum juga telah dilakukan. Penelitian sebelumnya menunjukkan bahwa kecenderungan rasa bersalah dapat menjadi faktor pelindung dari melakukan kejahatan, namun tidak ada bukti bahwa rasa malu memiliki fungsi penghambat dari melakukan kejahatan (Tangney, Stuewig, Mashek, \& Hastings, 
2011). Hasil penelitian Tangney, Stuewig, dan Martinez (2014) juga menjelaskan bahwa narapidana yang merasa bersalah atas perilaku mereka lebih mungkin untuk dapat keluar dari penjara di kemudian hari jika dibandingkan dengan mereka yang cenderung merasa malu pada diri sendiri. Temuan itu menggambarkan bahwa orang yang merasa bersalah atas perilaku mereka, akan mengalami ketegangan, penyesalan mendalam, dan kecewa yang biasanya memotivasi diri mereka untuk memperbaiki tindakan dengan cara mengaku, meminta maaf, atau memperbaiki kerusakan yang dilakukan. Studi longitudinal Hosser, Windzio, dan Greve (2008) juga menemukan indikasi bahwa rasa bersalah saat mulai menjalani hukuman di penjara berhubungan dengan rendahnya tingkat residivisme, dan rasa malu berkorelasi dengan tingginya angka residivisme yang lebih tinggi.

Menimbang berbagai hasil penelitian sebelumnya, dapat diketahui bahwa penelitian psikologis yang membedakan antara narapidana baru dan narapidana residivis lebih banyak berfokus pada aspek kepribadian saja. Sedangkan penelitian yang cukup penting tentang perilaku kejahatan, yaitu rasa bersalah dan rasa malu, masih terbatas dilakukan pada narapidana umum. Berdasarkan hal tersebut, penelitian ini bertujuan untuk mengkaji perbedaan sifat kepribadian (personality traits), rasa bersalah (guilt) dan rasa malu (shame) pada pelaku kejahatan peredaran narkoba yang pertama kali menjadi narapidana (nonresidivis) dengan kelompok narapidana kasus narkoba residivis.

Residivisme didefinisikan sebagai setiap pemenjaraan kembali setelah bebas dari penjara (Grieger, Hosser \& Alexander, 2012). Residivisme dapat dimaknai juga sebagai jumlah hukuman pidana yang telah didapatkan seseorang, dan jumlah hukuman penjara yang dinyatakan (Međedović et al., 2012). Berbagai temuan menjelaskan bahwa sifat kepri-badian, rasa bersalah dan rasa malu merupakan faktor yang mem- pengaruhi pelaku kriminal. Studi ini ingin mengkaji lebih mendalam apakah ketiga faktor psikologis tersebut berbeda antara narapidana yang nonresidivis dan residivis. Penjelasan pertanyaan ini sangat strategis untuk mengidentifikasi resiko pengulangan dan mengenali kebutuhan program perlakuan yang tepat untuk perbaikan para narapidana pengedar narkoba di dalam lembaga pemasyarakatan.

\section{Metode}

\section{Sampel}

Penelitian dilakukan terhadap narapidana pengedar narkoba yang dihukum di Lembaga Pemasyarakatan (LP) Cibinong, Jawa Barat, Indonesia. Jumlah Narapidana pada Lapas Cibinong pada saat penelitian sebanyak 1111 narapidana, jumlah narapidana kasus narkoba sebagai pengedar adalah 495 orang (pengguna $n=275$ orang). Narapidana yang menyatakan bersedia untuk mengisi kuesioner adalah 115 narapidana dengan kasus bandar atau peredaran narkoba. Berdasarkan pertanyaan kuesioner dan pengecekan pada sistem database pemasyarakatan tentang pengulangan kasus kejahatan serupa (residivis) dan mendapat hukuman penjara, diperoleh $n=75$ narapidana pertama kali dihukum (nonresidivis), dan $n=40$ narapidana merupakan kasus yang kedua atau lebih (residivis).

\section{Pengumpulan Data}

Pengukuran sifat kepribadian pada penelitian ini menggunakan skala the big five personality traits (John \& Srivastava, 1999; MacCare \& Costa, 2006; Soto, 2018), terdiri atas 44 pernyataan dengan 5 pilihan jawaban $(1=$ sangat tidak setuju sampai dengan $5=$ sangat tidak setuju). Skala ini telah diadaptasi ke dalam bahasa Indonesia dan dilakukan uji validitas dan reliabiltas (Wibowo, Yudiana, Reswara, \& Jatmiko, 2017; Zahrani, 2018). Hasil analisis reliabilitas dengan alpha Cronbach 
dilakukan untuk memeriksa konsistensi internal instrumen dengan nilai 0.687 untuk openness, 0.846 untuk extraversion, 0.690 untuk agreeableness, nilai 0.787 untuk conscientiousness dan 0.816 untuk aspek neuroticism (Wibowo et al., 2017).

Pengukuran kecenderungan rasa bersalah dan rasa malu menggunakan Guilt and Shame Proneness Scale (GASP) dikembangkan oleh Cohen, Wolf, Panter dan Insko (2011). Skala ini memiliki dua subskala yakni Guilt proneness, terdiri dari delapan aitem pernyataan untuk indikator Guilt negative behavior-evaluations (Guilt NBE) dan Guilt repair. Subskala shame memiliki delapan pernyataan dari indikator shame negative self-evaluations (Shame NSE) and shame withdrawal. Pilihan jawaban untuk responden meliputi 7 respon (dari $1=$ sangat tidak mungkin hingga $7=$ sangat mungkin). Hasil uji validitas setiap aitem subskala Guilt menunjukkan keseluruhan aitem valid $(\mathrm{r}=0,608-0,725)$. Validitas subskala shame menghasilkan nilai yang signifikan pada setiap aitem $(r=0,525-0,732)$. Uji reliabilitas GASP mem-peroleh nilai r 0,735 .

\section{Analisis Data}

Sebelum dilakukan uji hipotesis, terlebih dahulu dilakukan uji asumsi normalitas dan homogenitas. Tes normalitas data responden nonresidivis dan residivis hasil pengukuran the big five personality menunjukkan data berdistribusi normal pada aspek extraversion, agreeableness, conscientiousness, dan openness ( $p>0.05)$, sedangkan data neuroticism menunjukkan tidak normal $(p<0.05)$. Tes homogenitas varian menunjukkan seluruh data aspekaspek dari big five personality adalah homogen $(p>0.05)$.

Hasil uji asumsi normalitas dan homogentitas pada data variabel rasa malu (shame proneness) menunjukkan skor responden nonresidivis (Sig. 0.200) dan residivis (0.163) bersifat normal dan homogen (Sig. 0.94) karena $p>0.05$. Sedangkan skor rasa bersalah (guilt proneness) menunjukkan data sampel normal pada kelompok residivis (Sig. 0.71) dan tidak normal pada kelompok nonresidivis $(p<0.05)$, namun skor kedua kelompok adalah homogen (Sig. 0.557).

Selanjutnya, uji hipotesis perbedaan ketiga variabel penelitian pada kelompok nonresidivis dan residivis dilakukan dengan t-test dengan bantuan program IBM SPSS Statistic version 25.0. for Windows.

\section{Hasil}

Deskripsi statistik pada Tabel 1 memperlihatkan persentasi usia responden $(N=$ $115, M=35.02, S D=9.26)$. Jumlah kelompok usia terbesar narapidana pada usia 2040 tahun (73.9\%). Dalam tahapan perkembangan psikologis usia ini berada pada periode masa dewasa awal. Narapidana berusia dewasa menengah (41-55 tahun) sebanyak $23.5 \%$, dan $2.6 \%$ narapidana dengan usia lebih dari 55 tahun (kelompok usia lanjut) dengan kasus kejahatan penjualan narkoba.

Gambaran latar belakang pendidikan menunjukkan sebagian besar responden narapidana pengedar narkoba pernah mengi-

Tabel 1. Deskripsi usia, status pernikahan, dan pendidikan partisipan

\begin{tabular}{lcc}
\hline \multicolumn{1}{c}{ Kriteria } & Jumlah & Prosentase \\
\hline Usia & & \\
20-40 tahun & 85 & 73.9 \\
41-55 tahun & 27 & 23.5 \\
$>$ 55 tahun & 3 & 2.6 \\
Status Pernikahan & & \\
Menikah & 49 & 42.6 \\
Belum menikah & 39 & 33.9 \\
Bercerai/Duda & 27 & 23.5 \\
Pendidikan & & \\
SD & 13 & 11.3 \\
SMP & 24 & 20.9 \\
SMA & 64 & 55.7 \\
Diploma & 9 & 7.8 \\
Sarjana & 5 & 4.3 \\
\hline
\end{tabular}


kuti pendidikan sekolah menengah pertama (SMP $=20.0 \%)$ dan sekolah menengah atas $($ SMA sederajat $=55.7 \%)$. Sedangkan responden narapidana pendidikan diploma dan sarjana $12.1 \%$ masih lebih besar daripada responden dengan pendidikan sampai SD (11.3\%). Status pernikahan responden narapidana pengedar narkoba yang paling banyak adalah masih menikah (42.6\%). Responden yang menyatakan belum menikah berjumlah $33.4 \%$ dan $23 . \%$ responden menyatakan sudah dalam status bercerai

Rata-rata lama hukuman (tahun) dari 115 responden penelitian ini adalah $M=$ $9.30(S D=2.90)$. Hukuman terendah responden adalah 5 tahun, yang tertinggi 20 tahun. Tidak ada responden penelitian ini yang mendapatkan hukuman seumur hidup atau hukuman mati. Tabel 2 menyajikan data masa hukuman tertinggi pada kelompok 5-8 tahun (47.8\%). Ada $13 . \%$ responden memperoleh vonis hukuman lebih dari 12 tahun, dan $39.1 \%$ narapidana dengan hukuman 9-12 tahun.

Deskripsi data residivisme $(\mathrm{N}=115)$ pada Tabel 2 menggambarkan sebagian besar sampel adalah narapidana baru pertama kali dipidana penjara kasus peredaran narkoba $(65.2 \%, n=75)$. Sedangkan responden dengan status residivis sejumlah $34.8 \% \quad(n=40)$. Meski statusnya sebagai pengedar narkoba, Sebagian besar para responden narapidana menyatakan bahwa mereka sebagai pengkonsumsi narkoba (9.6\% responden $(n=11)$ yang mengaku yang tidak menggunakan narkoba). Dua pertanyaan diajukan kepada responden : 1) apakah mereka mengkonsumsi narkoba? 2) tuliskan nama narkoba yang paling sering dikonsumsi dalam lima tahun terakhir. Gambaran jenis narkoba yang digunakan responden terbanyak adalah metamphetamine (63.4\%), seperti sabu-sabu dan esktasi. Jenis narkoba terbanyak kedua yang dikonsumsi responden ganja $(27.0 \%)$. Sabu-sabu dan ganja menurut undangundang narkorkita termasuk dalam kelompok Golongan I, sebagai jenis narkotika yang paling berbahaya, dengan kekuatan
Tabel 2. Masa hukuman dan pengalaman konsumsi narkoba

\begin{tabular}{lrc}
\hline & Jumlah & Prosentase \\
\hline Masa Hukuman & & \\
5-8 tahun & 55 & 47.9 \\
9-12 tahun & 45 & 39.1 \\
>12 tahun & 15 & 13.0 \\
Konsumsi narkoba & & \\
Tidak menkonsumsi & 11 & 9.6 \\
Metamphetamine & 73 & 63.4 \\
Ganja & 31 & 27.0 \\
Status residivisme & & \\
Nonresidivis & 75 & 65.2 \\
Residivis & 40 & 34.8 \\
\hline
\end{tabular}

adiktif sangat tinggi dan menimbulkan ketergantungan.

\section{Personality Traits pada Nonresidivis dan Residivis}

Uji perbedaan (Tabel 3 dan Tabel 4) menghasilkan extraversion $(\mathrm{F}=0.21, p>$ $0.05)$, conscientiousness $(\mathrm{F}=0.19, p>0.05)$ dan openness $(\mathrm{F}=0.15, p>0.05)$, yang berarti tidak adanya perbedaan nonresidivis dan residivis pada ketiga aspek dalam personality traits tersebut. Namun agreeableness $(\mathrm{F}=0.21, p<0.05, \mathrm{CI}=0.097,3.306)$ dan neuroticism $(\mathrm{F}=0.02, p<0.1, \mathrm{CI}=-3.40$, $0.09)$ menunjukkan perbedaan yang signifikan. Perbedaan agreeableness dan neuroticism pada nonresidivis dan residivis pada Tabel 3 secara lebih rinci terlihat pada masing-masing mean $(M)$. Agreeableness pada nonresidivis $\left(M_{\text {non-res }}=37.23, S=4.23\right)$ lebih besar daripada residivis $\left(M_{\text {res }}=35.53\right.$,

Tabel 3. Perbandingan personality traits nonresidivis dan residivis

\begin{tabular}{lcc}
\hline & Nonresidivis & Residivis \\
\cline { 2 - 3 } & Mean (SD) & Mean (SD) \\
\hline Extraversion & $26.79(4.11)$ & $26.43(3.88)$ \\
Agreeableness & $37.23(4.23)$ & $35.53(3.95)$ \\
Conscientious & $33.32(4.27)$ & $32.75(3.99)$ \\
Neuroticism & $20.72(4.59)$ & $22.38(4.31)$ \\
Openness & $35.53(4.49)$ & $34.98(4.59)$ \\
\hline
\end{tabular}


Tabel 4. Perbedaan Personality Traits Nonresidivis dan Residivis

\begin{tabular}{|c|c|c|c|c|c|c|c|c|c|c|}
\hline & & \multicolumn{2}{|c|}{$\begin{array}{l}\text { Levene's Test } \\
\text { for Equality } \\
\text { of Variances }\end{array}$} & \multicolumn{7}{|c|}{ t-test for Equality of Means } \\
\hline & & \multirow[b]{2}{*}{$\mathrm{F}$} & \multirow[b]{2}{*}{ Sig. } & \multirow[b]{2}{*}{$\mathrm{t}$} & \multirow[b]{2}{*}{ df } & \multirow{2}{*}{$\begin{array}{c}\text { Sig. } \\
(2- \\
\text { tailed) }\end{array}$} & \multirow{2}{*}{$\begin{array}{l}\text { Mean } \\
\text { Diff. }\end{array}$} & \multirow{2}{*}{$\begin{array}{c}\text { Std. } \\
\text { Error } \\
\text { Diff }\end{array}$} & \multicolumn{2}{|c|}{$95 \% \mathrm{CI}$} \\
\hline & & & & & & & & & Lower & Upper \\
\hline \multirow{2}{*}{ Extraversion } & $\begin{array}{l}\text { Equal } \\
\text { var.assumed }\end{array}$ & 0.21 & 0.64 & 0.46 & 113 & 0.648 & 0.36 & 0.79 & -1.20 & 1.92 \\
\hline & $\begin{array}{l}\text { Equal var. } \\
\text { not assumed }\end{array}$ & & & 0.47 & 83.74 & 0.642 & 0.36 & 0.78 & -1.18 & 1.90 \\
\hline \multirow{2}{*}{ Agreeableness } & $\begin{array}{l}\text { Equal } \\
\text { var.assumed }\end{array}$ & 0.21 & 0.65 & 2.10 & 113 & $0.04 * *$ & 1.70 & 0.81 & 0.09 & 3.30 \\
\hline & $\begin{array}{l}\text { Equal var. } \\
\text { not assumed }\end{array}$ & & & 2.14 & 84.50 & 0.035 & 1.70 & 0.79 & 0.12 & 3.28 \\
\hline \multirow{2}{*}{ Conscientiousness } & $\begin{array}{l}\text { Equal } \\
\text { var.assumed }\end{array}$ & 0.19 & 0.66 & 0.7 & 113 & 0.49 & 0.57 & 0.81 & -1.05 & 2.19 \\
\hline & $\begin{array}{l}\text { Equal var. } \\
\text { not assumed }\end{array}$ & & & 0.71 & 84.50 & 0.48 & 0.57 & 0.80 & -1.02 & 2.16 \\
\hline \multirow{2}{*}{ Neuroticism } & $\begin{array}{l}\text { Equal } \\
\text { var.assumed }\end{array}$ & 0.02 & 0.87 & $\begin{array}{c}- \\
1.88\end{array}$ & 113 & 0.06 & -1.65 & 0.88 & -3.40 & 0.09 \\
\hline & $\begin{array}{l}\text { Equal var. } \\
\text { not assumed }\end{array}$ & & & $\begin{array}{c}- \\
1.92\end{array}$ & 84.12 & $0.06^{*}$ & -1.65 & 0.86 & -3.37 & 0.06 \\
\hline \multirow{2}{*}{ Openness } & $\begin{array}{l}\text { Equal } \\
\text { var.assumed }\end{array}$ & 0.15 & 0.70 & 0.63 & 113 & 0.53 & 0.56 & 0.89 & -1.20 & 2.31 \\
\hline & $\begin{array}{l}\text { Equal var. } \\
\text { not assumed }\end{array}$ & & & 0.63 & 78.19 & 0.53 & 0.56 & 0.89 & -1.21 & 2.33 \\
\hline
\end{tabular}

Note. $\mathrm{t}$-tabel $(\mathrm{df}=113), * \mathrm{p}<0.1(\mathrm{t}=1.65845), * * \mathrm{p}<0.05(\mathrm{t}=1.98118)$

$S D=3.95)$. Data neuroticism sebaliknya memperlihatkan skor nonresidivis $\left(M_{\text {non-res }}\right.$ $=20.72, S D=4.59)$ lebih rendah daripada residivis $\left(M_{r e s}=22.38, S D=4.31\right)$. Sampel pengedar narkoba yang pertama kali menjalani hukuman penjara memiliki agreeableness yang lebih tinggi daripada sampel yang lebih dari satu kali mendapatkan hukuman penjara. Sedangkan neuroticism pengedar narkoba yang pertama kali menjalani hukuman penjara memiliki lebih rendah daripana yang lebih dari satu kali mendapatkan hukuman penjara.

Rasa Bersalah dan Rasa Malu pada Nonresidivis dan Residivis

Deskripsi statistik pada rasa bersalah dan malu (gambar 1) menunjukkan perbedaan mean yang sangat kecil. Rasa bersalah pada kelompok sampel nonresidivis ( $n$ = 75) adalah $M_{\text {non-res }}=44.57$ ) dan residi-vis $(n=40)$ sebesar $\left.M_{\text {res }}=53.57\right)$. Nilai mean rasa malu pada kelompok nonresi-divis $\left(M_{\text {non-res }}=33.30\right)$ dan residivis $\left(M_{\text {res }}=\right.$ 32.65). Uji perbedaan rasa bersalah $(\mathrm{F}=$
$0.346, p>0.05)$ dan rasa malu $(\mathrm{F}=0.06, p$ $>0.05)$ pada kelompok sampel nonresidivis menggunakan $t$-test menghasilkan tidak adanya perbedaan). Kesimpulan yang sama juga ditemukan pada subkomponen guilt proneness (Guilt NBE \& Guilt repair) dan shame proneness (Shame NSE dan Shame Withdraw).

Secara keseluruhan, uji perbedaan ra-

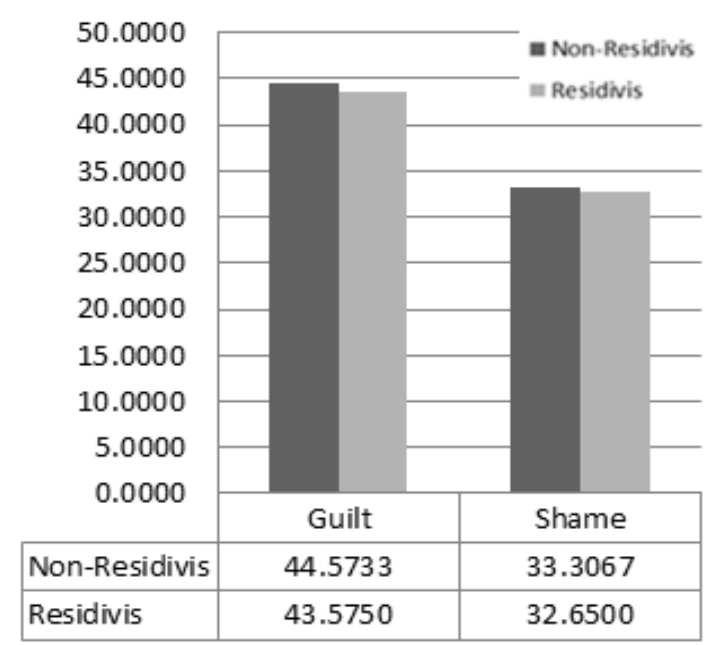

Gambar 1. Perbandingan Rasa Bersalah dan Malu Nonresidivis dan Residivis 

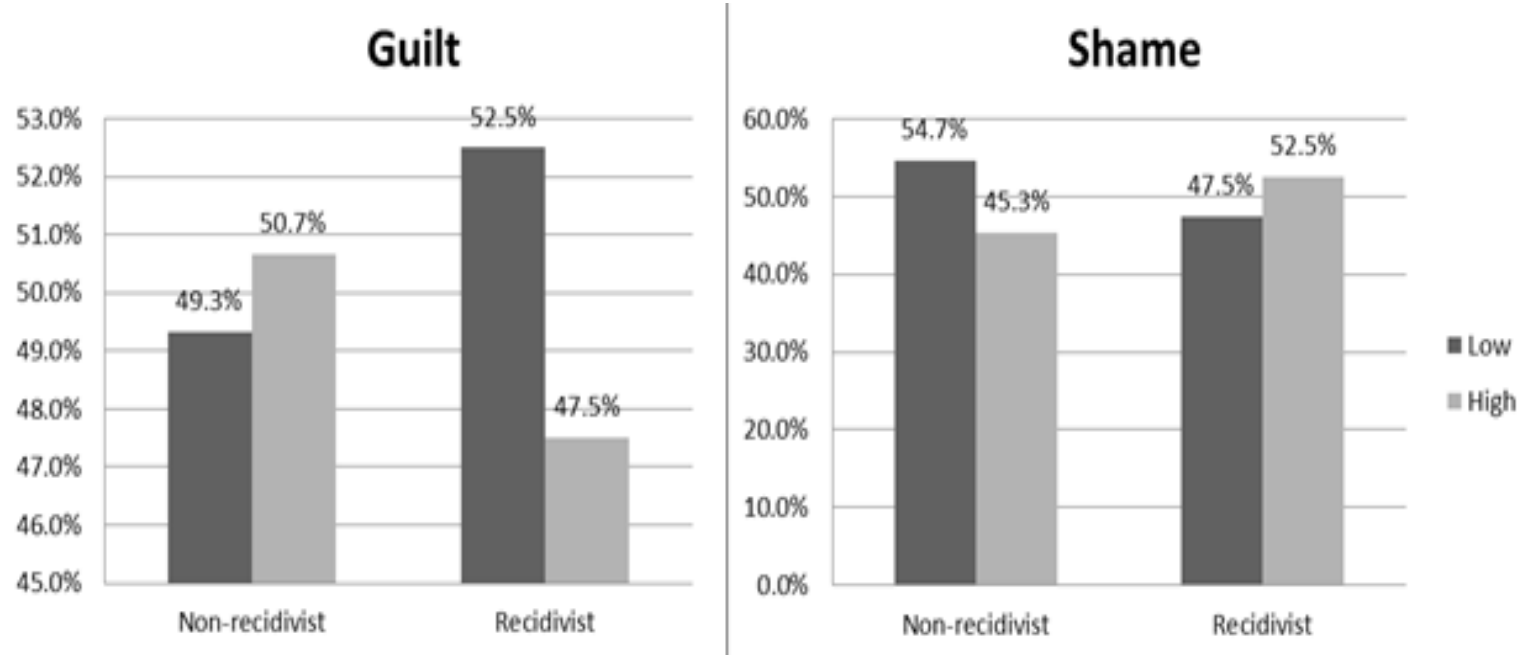

Gambar 2. Perbandingan Tingkat Rasa Bersalah dan Rasa Malu Nonresidivis dan Residivis

sa bersalah dan rasa malu pada sampel kelompok pengedar narkoba yang pertama kali dan lebih dari satu kali memperoleh pidana penjara menyimpulkan tidak ada perbedaan antar keduanya. Selanjutnya, jika masing-masing kelompok dibagi dalam tingkat low dan high (lihat Gambar 2), data pada aspek rasa bersalah menunjukkan tingkat low lebih banyak dimiliki oleh kelompok residivis $(52.5 \%)$, sementara rasa bersalah tingkat high lebih banyak ditunjukkan sampel nonresidivis (50.7\%). Namun, data pada kedua ssampel tidak menunjukkan perbedaan yang cukup signifikan $(\mathrm{F}=0.264, p>0.05)$. Pada aspek rasa malu, tingkat low lebih banyak dimiliki sampel nonresidivis $(54.7 \%)$, dan tingkat high lebih banyak muncul pada kelompok residivis $(52.5 \%)$. Namun, data aspek ini pada kedua sampel juga tidak menunjukkan perbedaan yang signifikan $(\mathrm{F}=2.744, p$ $>0.05)$.

\section{Pembahasan}

Gambaran faktor demografik responden menunjukkan pengedar narkoba didominasi narapidana berusia produktif 20-40 tahun $(73,9 \%)$, berstatus menikah atau pernah menikah $(66.1 \%)$ dan berpendidikan sampai dengan SMA (87.9\%). Studi tentang usia dan perilaku kejahatan umumnya menemukan bahwa aspek perkembangan otak berkaitan dengan kedewasaan emosional, pengambilan keputusan, dan pengambilan risiko, yang memuncak pada awal hingga pertengahan usia 20-an, namun cenderung menurun setelahnya (Ulmer \& Steffensmeier, 2014; Rocque \& Posick, 2016).

Pada masa dewasa, terutama usia menengah ke usia lanjut, masyarakat mengharapkan pelaku kejahatan mengurangi kejahatannya, berupaya berhenti dari kejahatan atau dari karir kriminal. Pada masa dewasa, terjadi akuisisi ikatan yang bermakna untuk individu dan institusi konvensional, seperti pekerjaan, perkawinan dan keluarga, dan masyarakat. Sedangkan para residivis menghadapi ancaman sanksi peradilan pidana yang semakin berat bagi pelaku dalam sistem hukum pidana di Indonesia. Seperti yang dinyatakan Pasal 144 UU Narkotika poin (1) menjelaskan bahwa Setiap orang yang dalam jangka waktu (tiga) tahun melakukan pengulangan tindak pidana, pidana maksimumnya ditambah dengan 1/3 (sepertiga). Sehingga semakin mempertimbangkan bahwa tindakan kejahatan merupakan hal yang tidak menguntungkan. Namun penjelasan terkait jenis kejahatan dan perkembangan psikologis usia dewasa ini berbeda pada konteks pengedar narkoba. Para pengedar narkoba 
umumnya didominasi narapidana berusia dewasa, dan masih atau pernah terikat dengan institusi perkawinan.

Latar belakang pendidikan pengedar narkoba yang dominan (sekolah dasar dan sekolah menengah) memperlihatkan keterkaitan hubungan pendidikan dengan kejahatan narkoba. Gambaran ini sejalan dengan hasil penelitian Veselak (2015) yang menyimpulkan bahwa pelaku dengan ijazah sekolah menengah lebih mungkin untuk dipenjara karena kejahatan terkait narkoba. Efek negatif yang signifikan dari tingkat pendidikan pada laki-laki yang dihukum dan ditahan juga telah ditemukan, dimana tambahan satu tahun tingkat sekolah mampu mengurangi kemungkinan para subjek untuk mendapatkan hukuman sebesar $6,7 \%$ dan mengurangi peluang penahanan sebesar 15,5\% (Hjalmarsson, Holmlund, \& Lindquist, 2015).

Lebih dari setengah pengedar narkoba yang menjadi sampel peneltian ini menga$\mathrm{ku}$ telah menggunakan narkoba berjenis metamphetamine $(63.4 \%)$ atau lebih dikenal dengan shabu, yaitu stimultan obat yang sangat adiktif. Menurut survei BNN (2019), shabu merupakan jenis narkotika peringkat kedua yang paling sering dikonsumsi oleh masyarakat (misalnya pekerja, pelajar dan rumah tangga). Shabu memberikan efek sebagai stimulan yang kuat yang sangat cepat pada otak dan akan menghasilkan euforia yang intens, meski cepat memudar hingga membuat pengguna sering memakainya berulang kali.

Berbagai kasus kejahatan narkoba menunjukkan adanya ketergantungan konsumsi narkoba pada pengedar narkoba. Menurut temuan Fakhrzadegan, GholamiDoon, Shamloo, \& Shokouhi-Moqhaddam (2017), 46,5\% dari populasi pelaku kejahatan telah mengembangkan ketergantungan narkoba pada saat melakukan kejahatan, dan para pengguna opium, methamphetamine, heroin, dan alkohol, yang memiliki tingkat penggunaan tertinggi, memiliki gangguan kepribadian. Penjelasan ini diperkuat dengan temuan bahwa prevalensi lebih tinggi konsumsi narkoba pada individu yang dihukum dengan kejahatan narkoba daripada pelaku kejahatan kekerasan (Håkansson \& Jesionowska, 2018).

Uji perbedaan personality trait dengan skala the big five personality me-nemukan agreeableness nonresidivis lebih tinggi $\left(\mathrm{M}_{\text {non-res }}=37.23\right)$ jika dibandingkan dengan residivis $\left(\mathrm{M}_{\mathrm{res}}=35.57\right)$. Temuan ini memperkuat kesimpulan studi Gul dan Jabeen (2015) yang menyimpulkan bahwa agreeableness pelaku kriminal lebih rendah dibandingkan dengan nonkriminal. Agreeableness berkenaan dengan kemampuan beradaptasi sosial dan tendensi kepatuhan, kerelaan, persahabatan, persetujuan, serta cinta. Orang dengan agreeableness yang tinggi memiliki sifat seperti kemurahan, kepercayaan, dan kehangatan yang kontras dengan sifat seperti permusuhan, selfish, dan ketidakpercayaan (Goldberg, 1993). Individu dengan agreeableness tinggi memiliki rasa, percaya, meyakini hal terbaik pada diri orang lain dan jarang mencurigai niat tersembunyi orang lain (MacCare \& Costa, 2006).

Agreeableness merupakan dimensi penting untuk menilai individu dalam suatu kelompok (Graziano \& Eisenberg, 1977). Individu dengan agreeableness rendah menunjukkan kecenderungan untuk tidak kooperatif, hingga relasi sosial dan ikatan dengan norma kelompok menjadi rendah. Penner dan Fritzsche (dikutip oleh Graziano \& Eisenberg, 1977) serta Soto (2018) menjelaskan bahwa agreeableness memiliki hubungan yang dekat dengan simpati, orientasi pemahaman moral terhadap orang lain, afiliasi dan perilaku prososial. Agreeableness dapat menjadi prediktor tambahan yang signifikan terhadap faktor antisosial, sebagai faktor prediktor residivisme, sehingga semakin rendah agreeableness dan semakin tinggi antisosial, maka semakin tinggi peluang narapidana menjadi residivis (Mededović, Kujačić, \& Knežević, 2012; Jones, Miller, \& Lynam, 2011). Agreeableness juga da- 
pat memprediksi tindak kejahatan di masa depan berdasarkan faktor criminal thinking dan moral disengagement (Walters, 2018). Temuan tingkat agreeablenes yang tinggi pada kelompok nonresidivis pada penelitian ini memperlihatkan bahwa mereka masih mempunyai kecenderungan lebih besar untuk berafiliasi, membangun ikatan dengan norma dan kelompok sosial dibanding kelompok residivis. Sampel nonresidivis memiliki potensi untuk perbaikan lebih besar jika diberikan perlakuan yang tepat dan berinteraksi dengan kelompok sosial yang baik, serta memutus interaksi dengan ling-kungan penyalahguna narkoba dan pengedar narkoba.

Penelitian ini juga menemukan bahwa skor neuroticism pada narapidana pengedar narkoba residivis adalah lebih tinggi $\left(M_{r e s}=22.38\right)$ daripada nonresidivis $\left(M_{r e s}=\right.$ 20.72). Neuroticism dalam konsep the big five personality menggambarkan stabilitas emosi, dan berkaitan dengan perbedaan frekuensi dan intensitas emosi yang negatif (Soto, 2018). Individu yang memiliki level neuroticism tinggi rentan untuk mengalami kecemasan, keta-kutan, tidak tenang dan emosi mudah berubah, dan menunjukkan reaksi fight and flight dalam sistem syaraf (Van Dam, De Bruyn, \& Janssens, 2007; Dash et al., 2019). Hasil studi Sulhin dan Hendiarto (2011) sebelumnya menjelaskan gambaran salah satu determinan residivisme pada narapidana di Indonesia pada faktor emosi dan kepribadian yang tidak stabil. Kesimpulan studi yang menunjukkan narapidana pengedar narkoba residivis memiliki neuroticism lebih tinggi, menguatkan hasil penelitian yang menyimpulkan bahwa neuroticism lebih tinggi cenderung dimiliki para pelaku kejahatan daripada individu normal (Addad \& Leslau, 1989).

Individu dengan neuroticism tinggi, menurut John dan Srivastava (1999), memiliki sifat mudah tersinggung, impulsif, moody, dan vulnarable. Sehingga Individu neuroticism dengan stabilitas emosi rendah mempunyai afek yang negatif dan mudah gelisah. Penelitian perbandingan kelompok kriminal dan kelompok normal menemukan dalam skor stabilitas emosi, yang ditunjukkan dengan lebih rendahnya stabilitas emosi kelompok kriminal daripada kelompok normal (Sinha, 2016). Eysenck dan Eysenck (dikutip oleh Addad \& Leslau, 1990) juga menjelaskan mengenai adanya hubungan delinkuensi dengan tipe kepribadian seperti neuroticism. Lebih tingginya neuroticism pada residivis menunjukkan bahwa mereka lebih impulsif, cemas dan memiliki kecenderungan gangguan mental yang lebih tinggi (Pabbathi, Naik, Mandadi, \& Bhogaraju, 2014).

Kajian hubungan kepribadian dengan perilaku kriminal menjadi topik utama bidang psikologi kriminal (Krueger et al., 1994). Sejumlah teori psikologi kriminal menjelaskan bukan hanya berfokus pada karakteristik pengalaman inividual, tetapi juga penyesuaian emosional dan personalitiy traits. Personality traits mampu memprediksi cara berpikir yang menjadi karakteristik penjahat yang menetap (Boduszek, Shevlin, Adamson, \& Hyland, 2013). Temuan Eysenck dan Eysenck (1977) dan Laiberg (2015) menegaskan kesimpulan kepribadian berkaitan dengan kejahatan ini berdasarkan hasil studinya yang menemukan bahwa ada perbedaan yang signifikan dalam jenis kepribadian (psychoticism dan neuroticism) antara sampel narapidana dan bukan narapidana. Demikan juga, penelitian terhadap enam dimensi kepribadian dalam model HEXACO (honesty-humility, emotionality, extraversion, agreeableness, conscientiousness, openness to experience) menyimpulkan bahwa pelaku kejahatan berbeda dengan bukan pelaku kejahatan pada semua aspek kepribadian tersebut (Rolison, Hanoch, \& Gummerum, 2013).

Hasil penelitian kali ini mendukung berbagai penelitian sebelumnya tersebut bahwa ada perbedaan personality traits pada pelaku kejahatan, yaitu narapidana pengedar narkoba yang baru pertama kali dihukum penjara menunjukkan tingkat agreeableness lebih tinggi dan neuroticism yang lebih rendah dibandingkan dengan 
narapidana yang lebih dari satu kali dihukum penjara.

Perbedaan rasa bersalah dan rasa malu antara nonresidivis dan residivis pada penelitian ini tidak ditemukan signifikansinya. Kesimpulan studi ini agak berbeda dengan hasil temuan penelitian Tangney, Stuewig, dan Martinez (2014) dan Hosser et al. (2008) yang menyimpulkan bahwa guilt-proneness secara negatif dan langsung, memprediksi kembali pelanggaran pada tahun pertama setelah bebas, sedangkan aspek shame proneness tidak menjadi prediktor residivisme yang kuat, kecuali dengan pemodelan mediational melalui externalizatioan dan blame.

Rasa malu berkaitan dengan perasaan yang rentan dengan kurangnya kepercayaan, perasaan tidak berharga, ketidakberdayaan, dan keinginan untuk bersembunyi secara sosial (Duncan \& Cacciatore, 2015). Tangney, Stuewig dan Mashek (2007) menyatakan bahwa rasa malu ditimbulkan oleh berbagai situasi yang lebih luas termasuk kegagalan dan pelanggaran moral maupun nonmoral. Perbandingan rasa malu antara pengedar narkoba nonresidivis dan residivis, menunjukkan bahwa sebagian besar nonresidivis memiliki level rasa malu yang rendah. Sedangkan pada kelompok residivis justru sebagian besar berada pada level rasa malu yang tinggi. Berdasarkan penjelasan konsep rasa malu (shame), temuan studi ini menggambarkan bahwa para nonresidivis memiliki kecenderungan masih memiliki kepercayaan, perasaan berharga dan berdaya. Hal ini berbeda dengan para pengedar narkoba residivis yang mengindikasikan dirinya tidak percaya, merasa gagal, tidak berharga secara sosial, dan menunjukkan keinginan kuat untuk bersembunyi dari kelompok sosial.

Studi ini menunjukkan adanya skor yang relatif sama terkait tingkat rasa bersalah dan rasa malu yang rendah antara pengedar narkoba residivis dan bukan residivis. Pengedar narkoba umumnya memiliki rasa bersalah yang tinggi $(56,52 \%)$, dan rasa malu yang rendah $(52,17 \%)$. Rasa bersalah berkaitan dengan perasaan individu telah melakukan suatu perbuatan yang buruk, menilai dirinya telah melanggar larangan yang diberlakukan oleh superego dan berusaha mengoreksi atas tindakan pelanggaran yang dilakukannya (Cohen, Wolf, Panter, \& Insko, 2011; Teroni \& Deonna, 2008). Gambaran rasa malu para pengedar yang rendah menunjukkan munculnya perasaan gagal untuk memenuhi standar yang ditetapkan oleh ego-ideal, dan norma sosial. Rasa malu dihasilkan ketika seseorang menilai adanya ketidaksesuaian antara persepsi diri sendiri dengan orang lain terhadap suatu tindakan yang melanggar norma ideal. Para pengedar mengalami perasaan negatif yang muncul ketika kegagalan atau kekurangan seseorang diketahui oleh masyarakat, dan cenderung untuk menarik diri dan menyembunyikannya (Cohen et al., 2011).

Rendahnya rasa malu pada sampel penelitian ini selaras dengan hasil penelitian sebelumnya yang menemukan masalah psikologis dalam diri para penyalahguna narkoba, yaitu gangguan kepribadian (Wolf, Patterson, \& Grande, 1988) dan kepribadian antisosial (Grande, Wolf, Schubert, Patterson, \& Brocco, 1984; Schulz, Murphy, \& Verona, 2016). Kepribadian antisosial atau psikopatik mencakup berbagai karakteristik seperti defisit empati yang serius, kurangnya rasa bersalah, impulsif, kurang empatik, tidak bertanggung jawab, dan perilaku antisosial (Hare \& Neumann, 2008; Hervé, Hayes, \& Hare, 2003). Hasil penelitian kali ini mendukung penjelasan bahwa orang dengan skor tinggi dalam psikopati primer memiliki lebih banyak kesulitan (kurang akurat) dalam membedakan antara kejadian yang menimbulkan rasa bersalah dan kejadian yang menimbulkan rasa malu (Djeriouat \& Trémolière, 2020).

\section{Simpulan}

Penelitian ini menyimpulkan bahwa 
ada perbedaan personality traits dalam agreeableness yang menunjukkan kelompok nonresidivis memiliki skor lebih tinggi dan nueroticism yang lebih rendah dibandingkan dengan residivis. Sedangkan dimensi extraversion, agreeableness dan conscientiousness tidak menunjukkan perbedaaan di antara kedua jenis kelompok pengedar narkoba itu. Pada aspek moral emosi, rasa bersalah dan rasa malu antara nonresidivis dan residivis tidak ditemukan adanya perbedaan. Namun, skor rasa bersalah para pengedar narkoba dalam penelitian ini memperlihatkan kelompok residivis sebagian besar memiliki rasa bersalah yang rendah, sementara kelompok nonresidivis umumnya mempunyai rasa bersalah yang tingi. Perbandingan rasa malu antara pengedar narkoba yang nonresidivis dan residivis menunjukkan bahwa nonresidivis sebagian besar memiliki rasa malu yang rendah. Sebaliknya, kelompok residivis sebagian besar berada pada level rasa malu yang tinggi.

Implikasi studi ini merekomendasikan perlunya program pembinaan mental kepribadian narapidana pengedar narkoba yang diarahkan pada pengembangan sifat kepribadian terbuka agreeableness, rasa malu, dan pengendalian aspek neuroticism. Agreeableness dan rasa malu berkaitan dengan kemampuan narapidana pengedar narkoba dalam mengintegrasikan norma masyarakat dan beradaptasi dengan norma tersebut. Sedangkan neuroticism berhubungan dengan kemampuan mengelola emosi. Karena itu, pembinaan kecerdasan emosional, bimbingan kerohanian, dan proses asimilasi dapat dilakukan untuk mencegah pengulangan kejahatan.

\section{Daftar Pustaka}

Addad, M., \& Leslau, A. (1989). Extraversion, neuroticism, immoral judgment and criminal behaviour. Med Law, 8(6), 611-622. PMID: 2517995

Addad, M., \& Leslau, A. (1990). Immoral judgment, extraversion, neuroticism, and criminal behaviour. International Journal of Offender Therapy and Comparative Criminology, 1-13. https://doi.org/10.1177/0306624X900340 0102

Angkasa. (2010). Over capacity narapidana di lembaga pemasyarakatan, faktor penyebab, implikasi negatif, serta solusi dalam upaya optimalisasi pembinaan narapidana. Jurnal Dinamika Hukum, 10(2), 213-221. http://dx.doi.org/10.20884/1.jdh.2010.10. 3.46

APA. (2014). After committing a crime, guilt and shame predict re-offense. (February). Retrieved from https://medicalxpress.com/news/2014- 02-committing-crime-guilt-shame-reoffense.html

Bachtiar, M. A. (2020). Strategi pembinaan kemandirian terhadap narapidana residivis narkotika (Studi kasus di Lembaga Pemasyarakatan Klas IIA Sidoarjo ). Jurnal Ilmu Hukum Dan Humaniora, 7(1), 103-115. http://jurnal.umtapsel.ac.id/index.php/Justitia/article/v iew/1461

Boduszek, D., Shevlin, M., Adamson, G., \& Hyland, P. (2013). Eysenck' $\mathrm{s}$ personality model and criminal thinking style within a violent and nonviolent offender sample: Application of Eysenck' s Personality model and criminal thinking style within a violent and nonviolent offender sample: Application of propensit. Deviant Behavior, 34, 483493.https://doi.org/10.1080/01639625 .2012 .748628 
Badan Narkotika Nasional. (BNN). (2019, Januari 8). Daftar Tempat Rehabilitasi Narkoba di Indonesia. Retrieved https://bnn.go.id/daftar-tempatrehabilitasi-narkoba-di-indonesia/

Badan Pusat Statistik (BPS). (2020). Statistik Kriminal 2020. Badan Pusat Statistik.

https://www.bps.go.id/publication/202 0/11/17/0f2dfc46761281f68f11afb1/st atistik-kriminal-2020.html

Clower, C. E., \& Bothwell, R. K. (2001). An exploratory study of the relationship between the Big Five and inmate recidivism. Journal of Research in Personality, 35, 231-237. https://doi.org/10.1006/ jrpe.2000.2312

Cohen, T. R., Wolf, S. T., Panter, A. T., \& Insko, C. A. (2011). Introducing the GASP Scale: A New Measure of Guilt and Shame Proneness. Journal of Personality and Social Psychology, 100(5), 947-966. https://doi.org/ $10.1037 / \mathrm{a} 0022641$

Dash, G. F., Slutske, W. S., Martin, N. G., Statham, D. J., Agrawal, A., \& Lynskey, M. T. (2019). Big five personality traits and alcohol, nicotine, cannabis, and gambling disorder comorbidity. Psychology of Addictive Behaviors, 33(4), 420-429. https://doi.org/10.1037/adb0000468

Delinda, A. D. (2017). Peran lembaga pemasyarakatan dalam rehabilitasi terhadap narapidana narkotika (Studi di Lembaga Lemasyarakatan Narkotika Klas IIA Jakarta). Jurnal Poenale, 5(2). https://garuda.ristekbrin.go.id/docume nts/detail/618506

Djeriouat, H., \& Trémolière, B. (2020). Shame and guilt situational identification in subclinical primary psychopaths. Current Psychology, 39(1), 238-245. https://doi.org/

\section{$10.1007 / \mathrm{s} 12144-017-9756-8$}

Duck, W. (2014). Becoming a drug dealer: Local interaction orders and criminal careers. Critical Sociology, 42(78), 1069-1085. https://doi.org/10.1177/ 0896920514552534

Duncan, C., \& Cacciatore, J. (2015). A systematic review of the peerreviewed literature on self-blame, guilt, and shame. Omega Journal of Death and Dying, 1-31. https://doi.org/10.1177/00302228155 72604

Eysenck, S. B. G., \& Eysenck, H. J. (1977). Personality differences between prisoners and controls. Psychological Reports, 40, 10231028. https://doi.org/10.2466/pr0. 1977.40.3c. 1023

Fakhrzadegan, S., Gholami-Doon, H., Shamloo, B., \& ShokouhiMoqhaddam, S. (2017). The Relationship between Personality Disorders and the Type of Crime Committed and Substance Used among Prisoners. Addiction \& Health, 9(2), 64-71. PMID: 29299208; PMCID: PMC5742412

Falkin, G. P., Wexler, H. K., \& Douglas S. Lipton. (1992). Drug Treatment in State Prisons. In D. R. Gerstein \& H. J. Harwood (Eds.), Treating Drug Problems (Vol. 2). Washington DC: National Academiy Press.

Goldberg, L. R. (1993). 'The structure of phenotypic personality traits": Author's reactions to the six comments. American Psychologist, 48(12), 1303-1304. https://doi.org/10.1037/0003-066x. 48.12.1303

Grande, T. P., Wolf, A. W., Schubert, D. S. P., Patterson, M. B., \& Brocco, K. (1984). Associations among alcoholism, drug abuse, and antisocial personality: A review literatur. 
Psychology Reports, 55, 455-474. https://doi.org/10.2466/pr0.1984.55.2. 455

Graziano, W., \& Eisenberg, E. (1977). Agreableness: A dimension of personality. In Hogan, R., Johnson, J. A., \& Briggs, S. R. (Eds.). Handbook of personality psychology. Hogan, R., Johnson, J. A., \& Briggs, S. R. (Eds.). (1997). Handbook of personality psychology. Academic Press. https://doi.org/10.1016/B978012134645-4/50031-7

Grieger, L., Hosser, D., \& Alexander F.Schmidt. (2012). The Predictive validity of self-control for different forms of recidivism. Journal of Criminal Psychology, Vol. 2 No. 2, 80-95. https://doi.org/10.1108/ 20093821211264405

Gul, N., \& Jabeen, T. (2015). Big five personality factors contribution in smuggling. The Science International, 27(4), 3821-3823. Retrieved from http://www.sci-int.com/Search? catid $=56$

Håkansson, A., \& Jesionowska, V. (2018). Associations between substance use and type of crime in prisoners with substance use problems - a focus on violence and fatal violence. Substance Abuse and Rehabilitation, 9, 1-9. https://doi.org/10.2147/sar.s143251

Hare, R. D., \& Neumann, C. S. (2008). Psychopathy as a clinical and empirical construct. Annual Review of Clinical Psychology, 4, 217-246. https://doi.org/10.1146/annurev.clinps y.3.022806.091452

Hervé, H. F., Hayes, P. J., \& Hare, R. D. (2003). Psychopathy and sensitivity to the emotional polarity of metaphorical statements. Personality and Individual Differences, 35(7), 14971507. https://doi.org/10.1016/S01918869(02)00365-3
Highland, R. A., \& Dabney, D. A. (2009). Using Adlerian theory to shed light on drug dealer motivations. Applien Psychology in Criminal Justice, 5(2), 109-138. http://www.apcj.org/ documents/5_2_1\%20Dabney.pdf

Hjalmarsson, R., Holmlund, H., \& Lindquist, M. J. (2015). The Effect of education on criminal convictions and incarceration: Causal evidence from micro-data. Economic Journal, 125(587), 1290-1326. https://doi.org/ 10.1111/ecoj.12204

Hosser, D., Windzio, M., \& Greve, W. (2008). Guilt and shame as predictors of recidivism: A longitudinal study with young prisoners. Criminal Justice and Behavior, 35(1), 138-152. https://doi.org/10.1177/00938548073 09224

Hudzaifi, A. (2017). Prisonisasi dan pembelajaran kejahatan di Lembaga Pemasyaratakan. Jakarta: Fakultas Ilmu Sosial dan Ilmu Politik UIN Syarif Hidayatullah. Retrieved from http://repository.uinjkt.ac.id/dspace/ha ndle/123456789/40938

Jones, S. E., Miller, J. D., \& Lynam, D. R. (2011). Personality, antisocial behavior, and aggression: A metaanalytic review. Journal of Criminal Justice, 39(4), 329-337. https://doi.org/10.1016/j.jcrimjus.201 1.03 .004

Krueger, R. F., Schmutte, P. S., Caspi, A., Moffitt, T. E., Campbell, K., \& Silva, P. A. (1994). Personality traits are linked to crime among men and women: Evidence from a birth cohort. Journal of Abnormal Psychology, 103(2), 328-338. https://doi.org/ 10.1037/0021-843X.103.2.328

Laiberg, S. (2015). Personality type, prediction and recidivist offending. Stockholm: Department of Criminology Stockholm University 
Retrieved from https://www.criminology.su.se/polopo ly_fs/1.271991.1456238122!/menu/st andard/file/2015c_Laiberg_Sigrid.pdf

Lo Coco, G., Melchiori, F., Oieni, V., Infurna, M. R., Strauss, B., Schwartze, D., Gullo, S. (2019). Group treatment for substance use disorder in adults: A systematic review and meta-analysis of randomized-controlled trials. Journal of Substance Abuse Treatment, 99, 104-116. 10.1016/j.jsat.2019.01.016

Mededović, J., Kujačić, D., \& Knežević, G. (2012). Personality-related determinants of criminal recidivism. Psihologija, 45(3), 277-294. https://doi.org/10.2298/PSI1203277M

Morgan, N., \& Del Fabbro, G. (2018). Factors associated with recidivism at a South African forensic psychiatric hospital. South African journal of psychiatry, $24 \quad$ (1125), 1-9. https://doi.org/10.4102/sajpsychiatry. v24i0.1125

Nainggolan, I. (2019). Lembaga pemasyarakatan dalam menjalankan rehabilitasi terhadap narapidana narkotika. EduTech: Jurnal Ilmu Pendidikan Dan Ilmu Sosial, 5(2), 136-149. https://doi.org/10.30596/ edutech.v5i2.3388

Pabbathi, L. R., Naik, U. S., Mandadi, G. D., \& Bhogaraju, A. (2014). Personality assessment of offenders and mentally ill offenders. $A P \quad J$ Psychol Med, 15(1), 55-59. https://www.amhonline.org/temp/Arc hMentHealth151552577006_070930.pdf

Prendergast, M. L., Podus, D., Chang, E., \& Urada, D. (2002). The effectiveness of drug abuse treatment: A metaanalysis of comparison group studies. Drug and Alcohol Dependence, 67(1),
53-72. https://doi.org/10.1016/S03768716(02)00014-5

R.MacCare, R., \& Paul T Costa, J. (2006). Personality in Adulthood: A FiveFactor Theory Perspective. In Transactional Analysis Journal (Second Ed, Vol. 36). New York: The Guildford Press.

Rocque, M., \& Posick, C. (2016). Age and Crime. In W. G. Jennings (Ed.), International Encyclopedia of the Social \& Behavioral Sciences: Second Edition. https://doi.org/10.1016/B9780-08-097086-8.45043-9

Rolison, J. J., Hanoch, Y., \& Gummerum, M. (2013). Characteristics of offenders: the HEXACO model of personality as a framework for studying offenders' personality. Journal of Forensic Psychiatry and Psychology, 24(1), 71-82. https://doi.org/10.1080/14789949.201 2.752024

Schulz, N., Murphy, B., \& Verona, E. (2016). Gender differences in Psychopathy Links to Drug Use. Law Human Behavior, 40(2), 159-168. https://doi.org/10.1037/lhb0000165

Semple, S. J., Strathdee, S. A., Volkmann, T., Zians, J., \& Patterson, T. L. (2011). High on my own supply: Correlates of drug dealing among heterosexually identified methamphetamine users. American Journal on Addictions, 20(6), 516524. https://doi.org/10.1111/j.15210391.2011.00173.x

Sinha, S. (2016). Personality correlates of criminals: A comparative study between normal controls and criminals. Industrial Psychiatry Journal, 25(1), 41-46. https://doi.org/10.4103/09726748.196058

Sistem Database Pemasyarakatan. (2020, Maret 28). Retrieved Oktober 11, 
2020 from http://smslap.ditjenpas. go.id/public/krl/current/monthly/year/ 2019/month/12

Soto, C. J. (2018). Big Five Personality Traits. In M. H. Bornstein, M. E. Arterberry, K. L. Fingerman, \& J. E. Lansford (Eds.), The SAGE encyclopedia of lifespan human development (pp. 240-241). https://doi.org/10.4135/97814129562 53.n67

Sulhin, I., \& Hendiarto, Y. T. (2011). Identifikasi faktor determinan residivisme. Jurnal Kriminologi Indonesia, 7(3), 355-366. http://journal.ui.ac.id/index.php/jki/art icle/view/1085

Tangney, June P., Stuewig, J., Mashek, D., \& Hastings, M. (2011). Assessing jail inmates' proneness to shame and guilt: Feeling bad about the behavior or the self? Criminal Justice and Behavior, 38(7), 710-734. https:// doi.org/10.1177/0093854811405762

Tangney, June P, Stuewig, J., \& Martinez, A. G. (2014). Two faces of shame: Understanding shame and guilt in the prediction of jail inmates' recidivism. Psychological Science, 25(3), 799$805 . \quad$ https://doi.org/10.1177/ 0956797613508790

Tangney, June Price, Stuewig, J., \& Mashek, D. J. (2007). Moral emotions and moral behavior. Annual Review of Psychology, 58(1), 345-372. https://doi.org/10.1146/annurev.psych .56 .091103 .070145

Teroni, F., \& Deonna, J. A. (2008). Differentiating shame from guilt. Consciousness and Cognition, 17(3), 725-740. https://doi.org/10.1016/ j.concog.2008.02.002

Tunnell, K. D. (1993). Inside the drug trade: Trafficking from the dealer's perspective. Qualitative Sociology, 16(4), 361-381. https://doi.org/

\subsection{7/BF00989970}

Van Dam, C., De Bruyn, E. E. J., \& Janssens, J. M. A. M. (2007). Personality, delinquency, and criminal recidivism. Adolescence, 42(168), 763-777.

https://pubmed.ncbi.nlm.nih.gov/1822 9510/

van Dam, C., Janssens, J. M. A. M., \& De Bruyn, E. E. J. (2005). PEN, Big Five, juvenile delinquency and criminal recidivism. Personality and Individual Differences, 39, 7-19. https://doi.org/10.1016/j.paid.2004.06 .016

Walters, G. D. (2018). Personality and crime: Mediating the agreeableness, offending and conscientiousness, offending relationships with proactive and reactive criminal thinking. Personality and Individual Differences, $\quad 129, \quad$ 166-170. https://doi.org/10.1016/j.paid.2018.03 .035

Wibowo, M. R. ., Yudiana, W., Reswara, I. P., \& Jatmiko, B. W. (2017). Reliability and Validity of the Indonesian Version of Big Five Inventory. UI Proceedings on Social Science and Humanities, 1(May 2017). http://proceedings.ui.ac.id/ index.php/uipssh/article/view/84

Wolf, A. W., Patterson, M., \& Grande, T. P. (1988). A statistical evaluation of the literature regarding the associations among alcoholism, drug abuse, and antisocial personality disorder. The International Journal of the Addictions, 23(8), 797-808. https://doi.org/10.3109/10826088809058 840

Zahrani, N. (2018). Uji Validitas Konstruk Pada Instrumen Self-Esteem Inventory Dengan Metode Confirmatory Factor Analysis (CFA). Jurnal Pengukuran Psikologi Dan Pendidikan Indonesia (JP3I), 5(1). 
https://doi.org/10.15408/jp3i.v5i1.924 1

Zilberman, N., Yadid, G., Efrati, Y., Neumark, Y., \& Rassovsky, Y. (2018). Personality profiles of substance and behavioral addictions. Addictive Behaviors, 82(March), 174181. https://doi.org/10.1016/j.addbeh. 2018.03.007 